coloração avermelhada com áreas claras alternando com áreas hemorrágicas. A consistência era macia e o tumor pesava $2,3 \mathrm{~kg}$, ao corte houve exsudação de líquido vermelho claro e a massa apresentava um aspecto gelatinoso. $\mathrm{O}$ laudo histopatológico com coloração hematoxilina-eosina revelou células com formato predominantemente estrelado distribuídas em um abundante estroma mucinoso fracamente basofilico com pequena quantidade de fibras colágenas, diagnosticando o mixossarcoma. A cadela recuperou-se bem não apresentando nenhuma alteração durante o periodo pós operatório imediato e após 15 meses não havia ocorrido recidiva. $\mathrm{O}$ relato deste caso ocorreu devido a natureza rara da neoplasia, além de seu tamanho, o qual não causava nenhuma alteração no trànsito intestinal.

Carvalho Filho, A.S.? Aptekmann, K.P. ${ }^{2} ;$ Schwartz, D.S. ${ }^{3}$; Calderón, C.'; Amorim, R.L. ${ }^{2}$; Rodrigues, M.M.P. ${ }^{2}$

\section{8 - Hemangiossarcoma cardíaco em cão. Relato de dois casos}

1- Pós-graduando do Departamento de Clínica Veterinária da Faculdade de Medicina Veterinária da Universidade Estadual Paulista, Campus de Botucatu, Botucatu-SP

2 - Residente do Departamento de Clínica Veterinária da Faculdade de Medicina Veterinária da Universidade Estadual Paulista, Campus de Botucatu, Botucatu-SP

3 - Professora Assessora Doutora do Departamento de Clínica Veterinária da Faculdade de Medicina Veterinária da Universidade Estadual Paulista, Campus de Botucatu, Botucatu-SP

O hemangiossarcoma é uma neoplasia maligna composta por células endoteliais que desenvolve-se mais frequentemente em cães do que em outras espécies. Estudos demonstram que é a neoplasia cardiaca mais comum e pode se desenvolver, mais comumente, em coração, baço, figado, músculo, tecido subcutâneo, pele e ossos. Geralmente, os tumores cardíacos primários em cães envolvem o lado direito do coração, especialmente o átrio direito. Em 01/08/02 foi atendido um canino, Boxer, macho, com 10 anos de idade e queixa de três episódios de síncope no dia anterior a consulta. Ao exame clínico o animal apresentava apatia, prostraçào, anorexia, emagrecimento progressivo, emese, aumento de linfonodos submandibulares e popliteos, hipotermia, bradicardia $(30 \mathrm{bpm})$, sopro sistólico com grau III/VI em foco de válvula mitral. $\mathrm{O}$ eletrocardiograma indicou a presença de bradicardia, bloqueio-átrio ventricular completo com complexos de escape ventricular e periodos intermitentes de ritmo idioventricular acelerado. A radiografia torácica indicou a presença de massa em região de átrio direito com desvio dorsal de traquéia na posição látero-lateral. O hemograma apresentava anemia normocitica normocrômica, leucocitose com neutrofilia e desvio à esquerda, monocitose, trombocitopenia e o perfil bioquímico revelava discreto aumento da fosfatase alcalina. A hemogasometria indicou a presença de acidose metabólica compensada e hipercaliemia. Foi realizada fluidoterapia com glicose 5 $\%$ com correçào do distúrbio ácido-básico e eletrolítico. A aplicação de atropina e aminofilina foram ineficazes na tentativa de aumentar da frequência cardíaca. $\mathrm{O}$ animal foi a óbito durante a introdução do marcapasso cardíaco externo. Na necrópsia o animal apresentava um tumor em base de coração direito que foi diagnosticado, posteriormente, como hemangiossarcoma por técnicas citológicas e de imunoistoquímicas para vimentina e fator VIII. A técnica imunoistoquímica também mostrou a presença de células neoplásicas infiltradas em miocárdio e tecido de condução que, provavelmente, estavam levando ao bloqueio átrio-ventricular completo. O segundo caso, atendido em $08 / 05 / 03$, tratava-se de um canino, Pastor Alemão, macho, com 10 anos de idade. $\mathrm{O}$ animal apresentava histórico de cansaço, anorexia e dificuldade em se locomover por alteraçào na coluna. Ao exame clínico observou-se dispnéia moderada e abafamento dos sons cardíacos à auscultação. $\mathrm{O}$ hemograma revelou anemia normocítica normocrômica. A radiografia torácica evidenciou um aumento generalizado da silhueta cardiaca, com desvio dorsal da traquéia e padrão pulmonar alveolar em lobo diafragmático. O eletrocardiograma não evidenciou alterações. Foi realizado o exame ecocardiográfico que revelou efusão pericárdica com massa intrapericárdica e tamponamento cardíaco. Foi realizada pericardiocentese com retirada de 1,2 litros de líquido, 
o qual foi analisado e classificado como transudato hemorrágico. Foi prescrito furosemida e enalapril, mas o animal veio a óbito no dia seguinte. A necrópia observou-se massa em átrio direito, carcaterizada como hemangiossarcoma cavernoso pelo exame histopatológico. Os cães com neoplasia cardíaca podem apresentar sintomatologia variada, a depender da localização, tamanho e infiltração do tumor. A confirmação do diagnóstico é realizada, freqüentemente, pela necrópsia e o prognóstico é ruim devido às limitações no tratamento.

\section{9 - Análise retrospectiva do Tumor Venéreo Transmissível (TVT) em cadelas, durante os anos de 1996 a 2002. Avaliação da resposta ao tratamento quimioterápico}

Bueno, M.G. '; Brito, C.P. ${ }^{2}$; Haipek, K.' ; Oliveira, C.M. ${ }^{3}$
1- Médica Veterinária estagiária do Serviço de Obstetrícia e Ginecologia do Hospital Veterinário da Faculdade de Medicina Veterinária e Zootecnia da Universidade de São Paulo, São Paulo-SP

2 - Pós-Graduanda do Departamento de Reprodução Animal da Faculdade de Medicina Veterinária e Zootecnia da Universidade de São Paulo, São Paulo-SP

3 - Professora Doutora do Departamento de Reprodução Animal da Faculdade de Medicina Veterinária e Zootecnia da Universidade de São Paulo, São Paulo-SP

O tumor venéreo transmissível (TV'T) é uma neoplasia de células redondas de origem mesenquimal e é um dos tumores que mais acomete a espécie canina. Geralmente afeta a genitália externa e é usualmente transmitido pelo coito. Outros sítios de ocorrência incluem: cavidade nasal, oral $\mathrm{e}$ tecido subcutâneo. A transmissão é feita entre a célula viável $\mathrm{e}$ a mucosa vaginal ou peniana lesada. A etiologia viral tem sido investigada mas ainda não foi verificada. O TVT tem distribuiçào mundial, mas predomina principalmente em paises de climas tropical e subtropical. Nào existe predisposição racial ou sexual para o TVT de ocorrência natural, porém, parece ser mais comum em animais jovens, errantes e sexualmente ativos. O diagnóstico definitivo é feito por exame histopatológico ou avaliação citológica do tumor. O TVT responde a muitas formas de terapia, tais como cirurgia e radioterapia, porém o tratamento mais efetivo e eficaz ainda é a quimioterapia. O prognóstico é bom, exceto nos animais que apresentam resistência ao tratamento, tendo que ser submetidos à excisão cirúrgica. Desta forma, foi realizado um estudo retrospectivo, que teve como objetivo obter informaçòes relativas às fêmeas caninas portadoras de TVT encaminhadas para tratamento ao Serviço de Ginecologia e Obstetrícia do HOVET - USP durante os anos de 1996 a 2002, assim como avaliar a ocorrência de resistência ao tratamento quimioterápico (Sulfato de Vincristina). O total de animais com TVT atendidos durante os 6 anos foi 341. Destes, $134(39 \%)$ responderam satisfatoriamente ao tratamento quimioterápico e foram considerados curados; $189(55 \%)$ não foram tratados por opção do proprietário ou o tratamento foi interrompido e $18(6 \%)$ mostraram resistência durante o tratamento e a resolução do quadro foi cirúrgica. Do total de animais curados, 34 (17\%) responderam com 2 a 3 aplicaçōes do medicamento, 59 (44\%), com 4 a 5 aplicaçōes, $37(27 \%)$ com 6 a 7 doses do quimioterápico e em $14(12 \%)$ foi necessária mais de 7 aplicações da droga para regressão do tumor. Nos animais que desenvolveram resistência 18 (95\%) deixaram de responder ao tratamento à partir da $6^{\mathrm{a}}$ aplicação. Foram anlisados $114(34 \%)$ animais com raça definida e $227(66 \%)$ sem raça definida. Além disso, $69(20 \%)$ animais pertenciam a faixa etária de 0 a 2 anos, $129(37 \%)$ de 3 a $5,85(24 \%)$ de 6 a 8 e $58(19 \%)$ maior que 8 anos. Concluiu-se que nos animais com TVT a maior porcentagem de cura foi obtida com 4 a 5 doses do Sulfato de Vincristina e nos animais que desenvolveram resistência ao medicamento foi necessário associar o tratamento cirúrgico para que houvesse resoluçào do quadro. A maioria dos animais pertenciam ao grupo dos animais sem raça definida e na faixa etária entre 3 a 5 anos. 